\title{
Comparative Analysis of the Effects of Classroom as against Online Mode of Instruction on Students' Psychomotor Performance in Woodwork Technology
}

\author{
Dr. Mrs. Chinyere Shirley Ayonmike \\ Department of Technical Education, \\ Faculty of Education, Delta State University, \\ Abraka, Nigreia
}

DOI: https://doi.org/10.36941/jesr-2020-0106

\begin{abstract}
The purpose of this study was to compare the psychomotor performance of students taught woodwork technology with classroom as against online mode of instruction in Nigerian Universities. Two research questions guided the study, as well, one (1) hypothesis was formulated and tested at .o5 level of significance. The quasi experimental design was used and the population of the study was 67 Undergraduate Students from the Department of Technical Education, Ebonyi State University Abakiliki. The sample of the study was 48 students comprising of 30 and 18 students from 1oolevel and zoolevel respectively. The instrument for data collection was the Woodwork Technology Practical Skills Assessment Instrument (WTPSAI) for measuring the psycho-performance of Woodwork Technology students in the manufacturing of stool, office chairs, door frame, panel door, and brace and batten door. The instrument was developed by the researcher which was content and face validated by 3 research experts from Delta State University Abraka, one from Measurement and Evaluation and the other two from Technical Education. Treatment was administered to the two experimental groups using two different mode of instruction, after which data were collected by the researcher through the administration of WTPSAI by lecturer from the institution selected for the study. Data collected were analysed using T-test to test the hypothesis. The study revealed that classroom and online mode of instruction for teaching and learning woodwork technology have significant effects on students' psychomotor performance in Woodwork Technology. Furthermore, unlike Classroom mode of instruction, Online Mode of Instruction appears to be more effective in terms of the acquisition of psychomotor skills. Based on the findings of the study, it was recommended among others that Woodwork Technology lecturers and instructors should integrate online mode of instruction in the implementation of Woodwork Technology curriculum which will aid in the production of competent woodwork Technology graduates that will be useful to him/her self and to the society.
\end{abstract}

Keywords: Analysis, Effects, Instruction, Classroom, Online, Psychomotor Performance, Woodwork Technology

\section{Introduction}

Technical Education is one of the key areas for human capital development in every aspect of our daily lives since it involves the acquisition of knowledge and practical skills. It is an important instrument for economic, industrial and infrastructural development. Bachelor of Science in Education (B.Sc. Ed.) Technical Education certificate is awarded by the universities to students who have fulfilled the University Faculty of Education requirements. According to National University Commission (NUC, 
2007), Technical Education programme is expected to make significant contribution to the Nigerian Education Industry, therefore Technical Education students are expected to:

i. Develop high level of skill in the design, production, and improvisation of various instructional technology resources.

ii. Acquire teaching skills and appropriate methods needed in imparting knowledge in their field of specializations.

iii. Demonstrate competency in the handling of various hardware to achieve maximum result for a wide variety of target audience.

iv. Gain insights on maintenance of industrial materials, tools, machines and facility.

v. Develop problem solving and creative thinking abilities.

vi. Develop safety consciousness, creativity and good judgment over the use of technology.

Despite these laudable objectives of Technical Education to produce competent Technical Education graduates who should be knowledgeable and possess skills in their areas of specialization such as Woodwork trade, Technical Education graduates still roam the street in search of jobs when these graduates are supposed to be employers of labour. This phenomenon may be traced to the various teaching methods used by Technical educationists to transfer knowledge and skills. It is a known fact that almost everyone uses electronic gadgets for communication and information sharing from the comfort of their homes and most people are getting addicted to these devices on a daily basis. These electronic technologies have because they are a must in the modern scheme of things, introduced to curriculum implementation in educational institutions in developed nations to compliment traditional teaching methods in the classroom.

Several researches have been conducted to examine the effects of traditional teaching methods like classroom mode of instruction, as against online mode of instruction, which show that traditional method of teaching is more effective than modern-day teaching method, like online mode of instruction.

Instruction is vital for education, as it is the transfer of learning from one person to another. Any time you are given directions or told how to do something you are receiving instruction (Vocabulary.Com, n.d). According to Huitt (2003) instruction is the purposeful direction of the learning process and is one of the major teacher/class activities. Professional educators have developed a variety of models of instruction, each designed to produce classroom learning. In summary, instruction (the purposeful guidance of the learning process) is complex and can take many forms. It is a vitally important classroom activity, but must be considered in the context of such factors as measures of desired student learning (including overlapping objectives taught to objectives tested), controlling student behaviour (classroom management activities), individual differences among students, and school processes and characteristics (Huitt, 2003). According to Law insider (n.d) classroom instruction means the purposeful direction of the learning process and training that takes place in a setting where individuals receiving training are assembled together and learn through lectures, study papers, class discussion, textbook study, or other means of organized formal education techniques. Also, classroom instruction is the teaching provided by a qualified teacher through face to face engagement of students in a formal school setting. While, online video instruction is the transfer of knowledge and skills to students using electronic and information technology facilities such as mobile phones and computers through the use of internet to students in different locations. According to (Joshua, n.d) online learning is the newest and most popular form of distance education today. Within the past decade it has had a major impact on postsecondary education and the trend is only increasing. Online learning is education that takes place over the Internet. It is often referred to as Elearning. However, online learning is just one type of distance learning (i.e. the umbrella term for any learning that takes place across distance and not in a traditional classroom). According to Tophat.Com (n.d), online instruction is an educational model where students and instructors connect via technology to review lectures, submit assignments and communicate with one another. No face-toface learning occurs since lectures, assignments and readings are delivered online. Hence, Online Video instruction is a distance learning that takes place in the internet using computers, laptops, and mobile 
phones for transfer of knowledge and skills.

Some researchers believed that the modern day modes of instruction are more effective in terms of students' performance. It is on these premises of various research reports regarding the performance of students, that the researcher saw the need to examine the effects of classroom and online mode of instruction for teaching and learning woodwork technology at the university level.

\section{Empirical Studies}

\subsection{Effectiveness of Classroom Mode of Instruction}

Adekoya and Olatoye (2011) reported that there is a significant effect of teaching using demonstration method on students' achievement in Agricultural Science. As well, Abdulhamid (2010) reported that demonstration method of instruction has significant effect on students' performance in Agricultural Science. In support, Ojenya (2005) reported that students taught using demonstration method of instruction performed better than those taught through lecture method.

\subsection{Effectiveness of Online Mode of Video Instruction}

Omiola, Enuwa, Awoyemi, and Bada (2012) study indicated that developed video instructional package enhances students' understanding of physics concepts, the acquisition of skills and as well improved students' performance in the subject. Also, Nikopoulou-Smyrni and Nikopoulos (2010) conducted a study to evaluate the impact of video-based versus traditional lectures on student learning. The researchers reported that teaching material based on video clips was equally effective as traditional lectures. In same vein, Theur, Greer and Turner (2011) research proved that the utilization of multimedia affect students' performance positively when compared to the conventional method of instruction.

Similarly, Gambari, Gbodi, and Olumba (n.d) reported that the students taught using video compact disc instructional package and those taught using audio compact disc instructional package performed significantly better than their counterparts taught using the normal classroom mode instruction. As well, Mosalanejad, Shahsavari and Sobhanian (2010) conducted a study on the effect of virtual versus traditional learning in achieving competency-based skills. The researchers reported that in theoretical examination, the mean score in the virtual teaching group was higher than the traditional group. Sadoon (2009) reported that students taught using technical audio- visual aids performed significantly better than students taught by the traditional method. More so, Osokoya (2009) study revealed that there is a significant difference between the mean score of students taught history with video tape instruction and students taught using conventional/traditional method of instruction. In addition, Ofem (2016) conducted a study titled Comparative Effects of Video Projection, Powerpoint Instructional Package and Traditional Teaching Methods on Students' Performance in Basic Science. The findings of the study revealed that video projection and PowerPoint instructional packages yielded higher performances than traditional teaching method. Also, Ayonmike and Okeke (2017) study on Instructional Technology in the Technical College Classroom to determine the effectiveness of three teaching methods namely: lecture, demonstration, and blended teaching on students' psychomotor performance in brick/block-laying and concreting in Delta State technical colleges revealed that effects on students' psychomotor performance in brick/block-laying and concreting. But the blended teaching method was found to be the most effective teaching method when compared to lecture and demonstration teaching.

However, Onasanya, Daramota and Asuquo (2006) reported that there is no significant difference in the performance of students exposed to individualized Computer Assisted Instruction (CAI) package and those exposed to the lecture method of instruction. As well, Spotts (1992) posited that the multimedia, CAI and control group did not differ significantly in terms of achievement gains, which implies that there was no significant difference in the performance of samples of both the experimental 
and control group. Cooper and Higgins (2014), conducted a study to examined the effectiveness of online instructional videos in the acquisition and demonstration of cognitive, affective and psychomotor rehabilitation skills. The study revealed that instructional videos can be used to successfully aid traditional learning for cognitive, affective and psychomotor skill acquisition. However, there is a trivial difference between two different durations of instructional videos, both having positive effects overall.

\section{Statement of Problem}

The performance of Technical Education students in practical related task has been worrisome. This has been confirmed by various Industrial Based Supervisors during Student Industrial Work Experience Scheme (SIWES) attachment as most Technical Education students find it difficult to perform basic practical tasks which involves display of practical competence in their trades of specialization such as Woodwork technology. This challenge of Technical education students not possessing the required practical knowledge and competence to perform industrial and practical task such as the construction of office chair, doors and door frames may be due to low quality on the part of the teachers, mode of instruction, availability of hand tools, machines, and consumable materials for teaching and learning practical skills. To address these challenges, it will be important for Technical Teachers to be innovative and creative in improving the teaching and learning of practical skills bearing in mind the current technological trend. In this regard, the use of online mode of instruction may have an effective impact on students' psychomotor performance. It would appear that there is no empirical evidence on the preference between classroom and online mode of instruction on students' psychomotor performance in woodwork technology. It is against this backdrop that this study sought to examine the effects of classroom as against online mode of instruction for teaching and learning woodwork technology on students' psychomotor performance.

\section{Purpose of the Study}

The major purpose of this study was to examine the effects of classroom and online mode of instruction for teaching and learning woodwork technology on students' psychomotor performance. Specifically, the study sought to:

1. Examine the psychomotor performance of students taught woodwork technology using classroom mode of instruction.

2. Examine the psychomotor performance of students taught woodwork technology using online mode of instruction.

3. Compare the psychomotor performance of students taught woodwork technology using classroom as against online mode of instruction.

\section{Significance of the Study}

The findings of this study will be of great benefits to Federal Ministry of Education and its agencies in charge of the implementation of Technical Education at the University level, State Ministry of Higher Education, Technical Education Lecturers, National Universities Commission (NUC), Technical Education Instructors, Curriculum Planners and Developers, Future Researchers, and University Administrators since the study will reveal the effects of using different modes of instruction on students psychomotor performance which will enable the stakeholders to know the areas that needs improvement. As well, the findings of the study will contribute significantly to the advancement of knowledge through publishing of this work in national and international reputable journals and other media such as magazines and newsletters. 


\section{Scope of the Study}

This study was delimited to modes of instruction such as: classroom (that is: face to face) and online. It covered both undergraduate regular and sandwich programmes. The study covered different skills areas in the construction of stool, office chair, door frame, panel door, and brace and batten door using hand tools, power hand tools, woodwork machines, and consumable materials (that is: wood, nails, fillers, adhesive and abrasive).

\section{Research Questions}

The following research questions guided this study:

1. What is the mean pre-test and post test psychomotor performance scores of students taught woodwork technology using classroom mode of instruction?

2. What is the mean pre-test and post test psychomotor performance scores of students taught woodwork technology using online mode of instruction?

\section{Hypothesis}

The following hypothesis was tested in this study at 0.05 level of significance:

1. There is no significant difference in the mean psychomotor performance scores of students taught woodwork technology using classroom as against online mode of instruction.

\section{Methods}

The quasi experimental research design was used for the study. Specifically, non- equivalent pretest, posttest experimental group design was used. The design was a $2 \times 2$ factorial design. This paradigm represents two levels of treatment, namely: classroom mode of instruction that is: face to face (experimental group1) and online mode of instruction (experimental group2). The population of the study comprised of all the 67 Undergraduate students from Department of Technical Education from Ebonyi State University Abakiliki in 2018/2019 academic session. The sample of the study was 48 students comprising of 30 and 18 students from 10olevel and 2oolevel respectively in 2018/2019 academic session. Intact class was used, the loolevel undergraduate students were used for the online group and zoolevel undergraduate students were used as the classroom group. The instrument for data collection for this study was the Woodwork Technology Practical Skills Assessment Instrument (WTPSAI) for measuring the psycho-performance of Woodwork Technology students in the manufacturing of stool, office chairs, door frame, panel door, and brace and batten door. The WTPSAI was developed by the researcher which has 21 practical tasks that were involved in the construction of stool, office chairs, door frame, panel door, and brace and batten door. The skill-tasks scoring is from 1-5 marks with an overall score of one hundred and five (105) marks. The instrument was content and face validated by 3 research experts from Delta State University Abraka, one from Measurement and Evaluation and the other two from Technical Education department. To ascertain the reliability of the WTPSAI, the instrument was administered to6undergraduate regular year one students from Department of Woodwork Technology, Federal University of Technology (FUT) Minna. The test retest method was used to ascertain the reliability of the instrument. After an interval of two weeks, the WTPSAI was re-administered to the same group of students. The data collected was used to ascertain the reliability of the instrument. The Pearson's product moment correlation technique was used to test the reliability of the instrument which yielded a reliability coefficient of 0.96 . In analysing the data, $t-$ test was used to test the hypothesis at 0.05 level of significance. 
The experiment lasted for seventeen (17) weeks. The experiment was carried out in stages which took the following order:

i. The researcher trained woodwork technology lecturers and made arrangement for the provision of consumable materials and assessment instrument ( 2 weeks).

ii. Pre- testing of students for the study by the woodwork technology lecturers (5weeks).

iii. Administration of treatment by woodwork technology lecturers (5weeks).

iv. Post-testing of students for the study by woodwork technology lecturers (5week)

\section{Results and Analysis}

\subsection{Results and Discussion}

The results were presented according to the research questions and hypothesis

Research Question 1: What is the mean pre-test and post test psychomotor performance scores of students taught woodwork technology using classroom mode of instruction?

Table 1: Mean pre-test and post test psychomotor performance scores of students taught woodwork technology using classroom mode of instruction

\begin{tabular}{|c|c|c|c|c|}
\hline Mode of Instruction & $\mathrm{N}$ & $\begin{array}{c}\text { Mean Score } \\
\text { Pre Test }\end{array}$ & $\begin{array}{c}\text { Mean Score } \\
\text { Post test }\end{array}$ & $\begin{array}{c}\text { Difference in } \\
\text { Mean Score }\end{array}$ \\
\hline Classroom & 18 & 15.00 & 54.44 & 39.44 \\
\hline
\end{tabular}

Table 1 shows that classroom mode of instruction for teaching and learning woodwork technology has effect on the performance of students, when, the Mean Pre-test score (15.0o) and the Mean Post-test score (54.44) were compared. This finding is in agreement with other works of researchers like Adekoya and Olatoye (2011), Abdulhamid (2010), and Ojenya (2005). These researchers believed that traditional mode of instruction is effective in teaching and learning. According to Adekoya and Olatoye (2011) there is a significant effect of teaching using demonstration method on students' achievement in Agricultural Science. In support, Abdulhamid (2010) reported that demonstration method of instruction has significant effect on students' performance in Agricultural Science. Similarly, Ojenya (2005) reported that students taught using demonstration method of instruction performed better than those taught with lecture method.

Research Question 2: What is the mean pre-test and post test psychomotor performance scores of students taught woodwork technology using online mode of instruction?

Table 2: Mean pre-test and post test psychomotor performance scores of students taught woodwork technology using online mode of instruction

\begin{tabular}{|c|c|c|c|c|}
\hline Mode of Instruction & $\mathbf{N}$ & $\begin{array}{c}\text { Mean Score } \\
\text { Pre Test }\end{array}$ & $\begin{array}{c}\text { Mean Score } \\
\text { Post test }\end{array}$ & $\begin{array}{c}\text { Difference in } \\
\text { Mean Score }\end{array}$ \\
\hline Online & 30 & 17.00 & 78.63 & 61.63 \\
\hline
\end{tabular}

Table 2 shows that online mode of instruction for teaching and learning woodwork technology has effect on the performance of students, when, the Mean Pre-test score (17.0o) and the Mean Post-test score (78.63) were compared. This finding is in line with the research findings of Omiola, Enuwa, Awoyemi, and Bada (2012), Nikopoulou-Smyrni and Nikopoulos (2010), Theur, Greer and Turner (2011), Gambari, Gbodi, and Olumba (n.d), Mosalanejad, Shahsavari and Sobhanian (2010), Sadoon (2009), Osokoya (2009), Ofem (2016), and Ayonmike and Okeke (2017). 
Omiola, Enuwa, Awoyemi, and Bada (2012) study indicated that developed video instructional package enhances students' understanding of physics concepts, the acquisition of skills and as well improved students' performance in the subject. Also, Nikopoulou-Smyrni and Nikopoulos (2010) reported that teaching material based on video clips was equally effective as traditional teaching. In same vein, Theur, Greer and Turner (2011) reported that the utilization of multimedia affect students' performance positively when compared to the conventional method of instruction. Similarly, Gambari, Gbodi, and Olumba (n.d) study shows that the students taught using video compact disc instructional package and those taught using audio compact disc instructional package performed significantly better than their counterparts taught using the normal classroom mode of instruction. As well, Mosalanejad, Shahsavari and Sobhanian (2010) reported that in theoretical examination, the mean score in the virtual teaching group was higher than the traditional group. Sadoon (2009) reported that students taught using technical audio- visual aids performed significantly better than students taught by the traditional method. More so, Osokoya (2009) study revealed that there is a significant difference between the mean score of students taught history with video tape instruction and students taught using conventional/traditional method of instruction. In addition, Ofem (2016) study revealed that video projection and PowerPoint instructional packages yielded higher performances than traditional teaching method. Also, Ayonmike and Okeke (2017) study revealed that blended teaching method was found to be the most effective teaching method when compared to lecture and demonstration teaching.

However, the findings of other researches are in disagreement with researchers like Onasanya, Daramota and Asuquo (2006), Spotts (1992), and Cooper and Higgins (2014). Onasanya, Daramota and Asuquo (2006) reported that there is no significant difference in the performance of students exposed to individualized Computer Assisted Instruction (CAI) package and those exposed to the lecture method of instruction. As well, Spotts (1992) posited that the multimedia, CAI and control group did not differ significantly in terms of achievement gains, which implies that there was no significant difference in the performance of samples of both the experimental and control group. Similarly, Cooper and Higgins (2014), study revealed that there was a trivial difference between two different durations of instructional videos, both having positive effects overall.

Hypothesis 1: There is no significant difference in the mean psychomotor performance scores of students taught woodwork technology using classroom as against online mode of instruction.

Table 3: Analysis of significant difference in the mean psychomotor performance scores of students taught woodwork technology using classroom as against online mode of instruction

\begin{tabular}{|c|c|c|c|c|c|}
\hline Mode of Instruction & N & Mean & Df & t-cal & Decision \\
\hline Classroom & 18 & 54.44 & \multirow{2}{*}{46} & -17.692 & \multirow{2}{*}{ Rejected } \\
\hline Online & 30 & 78.63 & & \\
\hline
\end{tabular}

Since t-tabulated at $\mathrm{df}(46)$ is 2.013 is greater than $\mathrm{t}$-cal (-17.692), the hypothesis which stated that there is no significant difference in the mean psychomotor performance scores of students taught woodwork technology using classroom and online mode of instruction was rejected, this implied that significant difference existed in the performance of students comparing the two methods in favour of online mode of instruction.

\section{Conclusion}

Based on the findings from the study it was concluded that classroom and online mode of instruction for teaching and learning woodwork technology have significant effects on students' psychomotor performance in Woodwork Technology. Furthermore, unlike Classroom mode of instruction, Online Mode of Instruction appears to be more effective in terms of acquisition of psychomotor skills. Hence there is the need to integrate online mode of instruction into the implementation of Technical Education for proper and effective teaching and learning of vocational skills. 


\section{Recommendations}

Based on the findings of the study, the following recommendations are made for effective implementation of Technical Education for improved skills acquisition:

i. School administrators and government should organize in-service training for Technical Education lecturers on the development and use of video instruction to teach practical skills.

ii. School administrators and government should provide grants for Technical Education lecturers and instructors to develop instructional materials for teaching and learning.

iii. Technical Education lecturers should embrace the use of video instruction for the implementation of woodwork technology curriculum.

iv. Technical Education lecturers should try as much as possible to use information communication technology gadgets such as mobile phones to teach students online.

\section{References}

Abdulhamid, A. (2010). Effects of two teaching methods on secondary school students' agricultural science performance in Bauchi metropolis Nigeria. Journal of Research in Education and Society. 1(1):1-12.

Adekoya, Y.M.\& Olatoye, R.A. (2011). Effect of demonstration, peer-tutoring, and lecture teaching strategies on senior secondary school students' achievement in an aspect of agricultural science. The Pacific Journal of Science and Technology, 12(1), 320-332.

Ayonmike, C.S. and Okeke, B.C. (2017). Instructional technology in the Technical College classroom: comparative analysis of effectiveness of traditional and blended teaching method on students' psychomotor performance. Journal of Education and Development in the Caribbean 16(1):89-108.

Cooper, D. \& Higgins, S. (2014). The effectiveness of online instructional videos in the acquisition and demonstration of cognitive, affective and psychomotor rehabilitation skills. British Journal of Educational Technology http://dx.doi.org/10.1111/bjet.12166

Cyril, M.U. (2016). Effects of multimedia instruction on retention and achievement of basic machining skills in Mechanical Craft Practice. International Journal of Education and Information Technology, 2(1):1-7.

Gambari, A.I., Gbodi, B.E., \& Olumba, R.N. (n.d). Effects of audio and video compact disc instructional packages on students performance in senior secondary schools phonetics in Minna Nigeria. Retrieved $5^{\text {th }}$ April 2014 from www.google.com.

Huitt, W. (2003). Classroom instruction. Educational Psychology Interactive. Valdosta, GA: Valdosta State University. Retrieved $12^{\text {th }}$ January 2018, from http://www.edpsycinteractive.org/topics/instruct/instruct.html

Joshua (n.d). Introduction to Online Teaching and Learning. Retrieved $12^{\text {th }}$ January 2018 fromhttp://www.wlac.edu/online/documents/otl.pdf

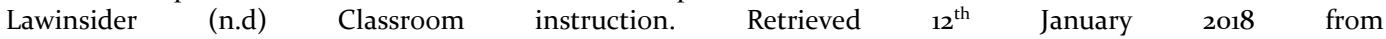
https://www.lawinsider.com/dictionary/classroom-instruction

Mosalanejad, L., Shahsavari, S., \& Dastpak,M. (2010). The effect of virtual versus traditional learning in achieving competency-based skills. Turkish Online Journal of Distance Education-TOJDE, 13(2), 1-7

National University Commission (NUC, 2007) Benchmark minimum academic standards for undergraduate programmes in Nigerian Universities. Abuja, NUC.

Nikopoulou-Smyrni, P. \& Nikopoulos, C. (2010). Evaluating the impact of video-based versus traditional lectures on student learning. Educational Research, 1(8), 304-311. Retrieved $5^{\text {th }}$ April 2014 from http://www.interesjournals.org/ER.

Ofem, I.B. (2016). Comparative effects of video projection, PowerPoint instructional package and traditional teaching methods on students' performance in Basic Science. The International Journal of Social Sciences and Humanities Invention, 3(11): 3050-3057.

Ojenya, F.O. (2005). How mathematics teachers use lecture and demonstration methods in the classroom. An Unpublished Under graduate Project of Benue State University, Makurdi.

Omiola. M. A., Enuwa M. R., Awoyemi S. O \&Bada A. A. (2012). Effect of developed video instructional package on the performance of senior secondary school physics students in Ilorin. British Journal of Science.6, (1), 45-54. http://www.ajournal.co.uk/pdfs/BSvolume6(1)/BSVol.6\%20(1)\%20Article\%2o6.pdf.

Onasanya, S.A., Daramola, F.O., \& Asuquo, E.N. (2006). Effect of computer assisted instructional package on secondary school students' performance in introductory technology in Ilorin Nigeria. The Nigeria Journal of Educational Media and Technology. 12 (1). 
Osokoya, I. O. (2009). Effects of video tape instruction on secondary school students achievement in history. Multidisciplinary Journal of Research Development. 12(1):120-129.

Sadoon, S.M. (2009). The effect of using technical audio visual aids on learning technical English language at technical institutes. Misan Journal for Academic Studies 8(15):1-12.

Spotts, D.S. (1992). Comparison of computer based training and conventional classroom training for technical instructions. Wright Patterson: Air Force Institute of Technology.

Theuri, P.M., Greer, B.M. \& Turner, L.D. (2011). The efficacies of utilizing a multimedia based instructional supplement on learners' cognitive skills. The Accounting Educators'Journal 21(1):107-129.

Tophat.Com (n.d). What is online instruction. Retrieved $12^{\text {th }}$ January 2018 https://tophat.com/glossary/o/onlineinstruction/Vocabulary.Com(n.d).

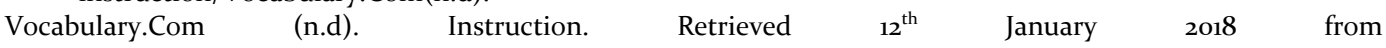
https://www.vocabulary.com/dictionary/instruction 